http://dx.doi.org/10.30681/23588403v14i0105

\title{
DESUMANIZAÇÃO E LITERATURA: UMA VISÃO DO HOMEM FRAGMENTADO NO CONTO A METAMORFOSE DE FRANZ KAFKA
}

\author{
Antonio Flávio Ferreira de OLIVEIRA (UEPB) ${ }^{1}$ \\ Cleiton da Silva Duarte LIRA (UEPB) ${ }^{2}$ \\ Data de recebimento: 05/09/2020 \\ Data de aceite: $23 / 11 / 2020$
}

\begin{abstract}
Resumo: Este trabalho investiga como a desumanização vem sendo representada discursivamente através da obra Metamorfose de Franz Kafka. A investigação foi fundamentada em Bauman (2001), Barthes (1977), Gasset (2001), entre outros. A partir da abordagem discursiva, foi observado como o protagonista Gregor Samsa é visto no contexto das revoluções industriais do século XX, a fim de identificar o modo como o personagem foi construído sob o espelho político-econômico novecentista. Como resultado, foi constatado que as transformações sociais promovidas pelo capitalismo afetaram significativamente o modo como a realidade passou a ser representada em nível de escrita literária.
\end{abstract}

Palavras-chave: Desumanização. Modernidade. Franz Kafka.

Abstract: This article investigates how the dehumanization has been represented discursively through the Metamorfose, a Franz Kafka's work. The investigation was grounded on Bauman (2001), Barthes (1977), Gasset (2001), among others. From a discursive approach, it was observed how the protagonist Gregor Samsa is seen in the century XX industrial revolutions context, in order to identify the manner how the character was constituted under the mirror of the XIX century political and economic revolutions. As a result, it was showed that the social transformations promoted by the capitalism affected significantly the manner how the reality became to be represented in the literary written level.

Keywords: Dehumanzation. Modernity. Franz Kafka.

\section{Introdução}

Em nossa pesquisa, buscamos identificar como a desumanização vem sendo retratada a partir da obra Metamorfose do autor alemão Franz Kafka (1883-1924), sobre a qual repousa o grande dilema das teorias sociológicas do século XX, que, de modo especial, pôs o homem no centro de uma discussão, na qual o sujeito estaria, de modo nocivo, subordinado a uma fratura de sua identidade e que, sobremaneira, descortina-se no protagonismo de Gregor

\footnotetext{
${ }^{1}$ Doutor em Linguística pelo Programa de Pós-Graduação em Linguística da Universidade Federal da Paraíba. flavioccaa@hotmail.com

${ }^{2}$ Graduando em Letras pela Universidade Estadual da Paraíba. cleitondlsr@gmail.com
} 
Samsa (personagem principal da obra kafkiana). Os termos deslocamento do sujeito e identidades fragmentadas são expressões tipicamente pós-modernas, que, a partir de pensadores como Stuart Hall (1932-2014) e Zygmunt Bauman (1925-2017), viriam a maximizar o sujeito, inserindo-o no campo dos fenômenos da cultura de massa e da vazão que potencializou a sua crise identitária.

O arcabouço teórico-metodológico mobilizado nesta pesquisa, como Hall (2006), Bauman (1995), Gasset (2001) e Barthes (1997), institui um horizonte epistemológico pelo qual a obra de Franz Kafka (1883-1924), Metamorfose, pode ser vista como uma regularidade social mecanizada pela força histórica do capitalismo. Nesse sentido, consideramos que isso modificou, em nível físico e psicológico, a fisionomia do indivíduo moderno, metaforizando, que, no decurso da narrativa, o personagem Gregor Samsa vai se tornando um inseto (uma barata) e perdendo a conexão com a sua própria realidade.

Ademais, foi identificada, a partir de um texto escrito por Antônio Cândido (19182017), a possibilidade do fazer literário como uma prática de humanização. O sustento desta inferência liga-se às discussões entre literatura e os direitos humanos problematizados por Cândido (2011), que analisou, a partir dos ideais de liberdade, igualdade e fraternidade da Revolução Francesa, a sutil contradição que se constituiu após os princípios humanitários dispostos na constituição francesa de 1948.

$\mathrm{O}$ interesse de nosso trabalho, mediante o qual aferiu-se o aspecto específico da desumanização, concentrou a sua análise a fim de verificar como a escrita literária representou a hecatombe promovida pelas transformações sociais do século XX, que incidiu, notadamente, na constituição identitária do sujeito para o qual entra a contribuição de Hall (2006), que elencou, em diferentes categorias, uma genealogia da identidade que foi pensada também no iluminismo.

A estrutura deste trabalho, além desta introdução e das considerações finais, está organizada em três seções. Na primeira seção, intitulada "Deixai toda esperança, vós que entrais!", exibimos as principais ideias que põem a desumanização em interface com a crise de identidade, representada pelo protagonismo do personagem Gregor Samsa, a partir do qual se sobreleva o aporte teórico-metodológico que serviu de base para conduzir a nossa discussão e nos elucidar quanto à inserção do personagem no contexto da centúria novecentista.

Na segunda seção, buscamos analisar o possível surgimento da desumanização como representação dentro do campo da literatura, problematizando o nosso objeto de pesquisa na 
transição da modernidade à pós-modernidade. Para tanto, foram apresentadas, como recurso teórico, as contribuições de Gasset (2001), que estabelecem, como centro de discussão, o distanciamento do ponto de vista estético entre o sujeito e a realidade em sua obra $A$ desumanização da arte. Na terceira seção, procuramos exibir o aspecto da decadência, como um discurso foi constituído no âmbito dos sujeitos, uma reação violenta da irrupção da regularidade social em fins do século XIX e do XX, que afetou todos os níveis da atividade social naquele contexto.

\section{Deixai toda esperança, vós que entrais! ${ }^{3}$}

A fase pós-moderna compreende uma instância movente de um homem descentralizado de sua própria razão, de sua unidade com o mundo e com a sociedade. $\mathrm{O}$ extravio dessa autorreferência de si implica, precisamente, na supressão de humanização robustecida pelos valores tradicionalmente difundidos no ocidente, no entanto, preconizados pela pós-modernidade. Mircea Eliade, cientista das religiões e filósofo romeno do século XX, em sua obra O Sagrado e o Profano, exibe, designadamente, o perfil do homem pós-moderno que, por sua vez, figura um homem moldado no advento das novas tecnologias, um homem mais individualizado, menos humano e mais desvencilhado do politicamente correto, cujos valores peculiares da cultura ocidental se concentram em princípios de ordem religiosa e, consequentemente, de natureza filosófica.

No século XIX, o filósofo alemão Friedrich Nietzsche já proclamava a dissolução da moral e dos valores outrora estabelecidos nos domínios do valor. Assim, em sua obra Assim Falava Zaratustra, esse filósofo enfaticamente prenuncia o limiar do caráter do novo homem, da nova sociedade, evidenciado pela postura que o profeta assumia em função de uma sociedade em que era enquadrado no círculo dos loucos, débeis mentais, isto é, tem-se subjacentemente a percepção, a representação de uma sociedade já dissociada de padrões considerados morais, portanto, corretos, e a representação de Zaratustra como um homem "ingênuo" e, ainda, tentando iluminar os homens que se obscurecem em sua ignorância. Ao

\footnotetext{
${ }^{3}$ Cf. Dante Alighieri. Canto III, a porta do inferno - Vestíbulo, Rio Aqueronte, Caronte. Disponível em: < https://www.stelle.com.br/pt/inferno/canto_3.html > Acesso em: 24 de agosto de 2020.
} 
tentar, por conseguinte, instaurar uma revolução da consciência, o profeta descobre que alguma coisa havia acontecido com aquelas pessoas: Deus estava morto ${ }^{4}$.

$\mathrm{Na}$ expressão Deus está morto, reflete-se a síntese de toda a obra, de toda a concepção existencial, social, cultural, política e humanitária que foi objeto de introspecção por Nietzsche. Antônio Cândido, sociólogo e crítico literário do século XX, escreve acerca de algumas utopias da sociedade moderna, em seu artigo $O$ Direito à Literatura, dentre as quais há uma colocação prototípica, que fora o sonho de que com a revolução industrial e a sua irremediável flexibilização nos segmentos de comunicação, conforto, saúde e educação, finalmente o gênero humano iria alcançar a ponderabilidade ou, como propuseram os gregos, - em a Ataraxia -, outra utopia do mundo antigo que visava à contemplação e à plenitude em detrimento dos prazeres carnais e das perturbações exteriores emitidas por conflitos sociais. Cândido (2011) adota como ponto de partida de sua discussão em O Direito à Literatura, dois constituintes inerentes à literatura, a saber, o princípio da negação e o da confirmação.

A literatura, segundo Cândido, viria incorporar esses dois referenciais, pois, construindo a relação entre Literatura e Direitos Humanos, o sociólogo vai dizer que, neste aspecto, a literatura vem confirmar a existência da desigualdade de caráter excludente, das elites intelectuais que monopolizam as obras tidas como eruditas e dificultam, em larga escala, o acesso a essas produções intelectuais por outras camadas sociais. Nesse sentido, esse estudo compreende, por via do novo paradigma do homem múltiplo e fragmentado da pósmodernidade, a constituição da forma a desumanização.

Para essa incursão, é imperativo que exibamos, em linhas gerais, algumas referências acerca da constituição da identidade e de sua representação com ênfase no realismo e, consequentemente, nalgumas produções literárias. A perspectiva que devemos adotar como interpretação das transformações sociais da modernidade tardia é a estabelecida por Hall (2006), em que a ênfase que se dá circunda as possíveis consequências da supressão do

\footnotetext{
4 “Deus está morto" é o aforismo que sintetiza a decadência do homem em relação aos princípios morais e éticos que eram, a rigor, disseminados pelo ocidente por intermédio do cristianismo e, de justo modo, pelas sociedades ditas civilizadas como, por exemplo, a sociedade da época do iluminismo (século XVII e XVIII); uma época em que os homens tentaram ressuscitar os valores voltados à liberdade, a economia e a política. A partir de Nietzsche e, consequentemente, de sua análise crítica sobre a sociedade do seu tempo, esses valores foram preconizados de modo a revelar a real natureza do homem, atribuindo-lhe em outra obra sua $A$ Vontade de Potência (1901), onde o gênero humano seria, em linhas gerais, movido pela sede de poder.
} 
sentido como indivíduo, em outras palavras, Hall (2006, p. 7) entende que a modernidade tardia está “[...] fragmentando o indivíduo moderno, até aqui visto como sujeito unificado".

A ideia de que o sujeito conserve uma única identidade possibilita-lhe, no que escreve Hall (2006, p. 7) uma “[...] ancoragem estável no mundo social”, e a ausência dela, implica, já de si, no que Stuart Hall vai chamar de crise de identidade. A fim de estabelecermos um panorama mais preciso acerca da identidade, iremos expor, inicialmente, algumas concepções de identidade desenvolvidas por Hall (2006) em sua obra A Identidade Cultural na Pós-modernidade. A condição para que o homem se desvincule de sua unidade parte do pressuposto de que um dia este já tivera essa unidade. Nesse segmento, em se tratando da concepção identitária no Iluminismo, Hall (2006) compreende que:

O sujeito do Iluminismo estava baseado numa concepção da pessoa humana como um indivíduo totalmente centrado, unificado, dotado das capacidades de razão, de consciência e de ação, cujo "centro" consistia num núcleo interior, que emergia pela primeira vez quando o sujeito nascia e com ele se desenvolvia, ainda que permanecendo essencialmente o mesmo - contínuo ou "idêntico" a ele - ao longo da existência do indivíduo (HALL, 2006, p. 10-11).

O sujeito pós-moderno representa a síntese dessas transformações radicais que se deram, a rigor, no âmbito cultural, político, econômico, ético e moral. Antes da Globalização e da força histórica do sistema capitalista, o sujeito era bombardeado por outros fatores sociais e culturais, como a nacionalidade - exaltada no romantismo do século XIX - ou com concentrados problemas do cotidiano, não envolvendo a esfera social como um todo.

Por isso que, no Iluminismo, o sujeito, mesmo apresentando um caráter de individualismo desenvolvido, como enfatiza Hall (2006), ele (o sujeito) ainda tinha sobre si uma esfera coesa, lógica de organização de si em relação ao mundo. Todavia, essas relações foram radicalmente transformadas pelo modernismo e delas sobreveio, consequentemente, o obscurantismo exacerbado que desembocou na inibição do sujeito em relação ao outro e em relação a si mesmo ${ }^{5}$. Bauman (2005), em sua obra Identidade: uma conversa com Benedetto

\footnotetext{
${ }^{5} \mathrm{O}$ que unia primitivamente as pessoas, excepcionalmente no pré-modernismo, era a ideia de sobrevivência coletiva, ou seja, as decisões eram pensadas no Outro. No tocante a isso, como pontua Bauman (2005) a origem primitiva da moral constitui a responsabilidade e, com a sua ausência, os laços se quebram dando margem a individualização do sujeito que não encontra mais sentido em se preocupar com o outro. Deste modo, argumenta Bauman: “[...] confrontamo-nos com o desafio do Outro, com o desafio da responsabilidade pelo Outro,
} 
Vecchi, nos provoca com o contínuo da utopia do homem pós-moderno - a de construir a sua identidade, buscando pertencimento em função do outro. Quanto a isso, Bauman (2005) diz que, “[...] a ideia de ter uma 'identidade' não vai ocorrer às pessoas enquanto o pertencimento continuar sendo o seu destino, uma condição sem alternativa" (BAUMAN, 2005, p. 17-18, grifo do autor). No mundo pós-moderno, já em processo corrosivo e presidido pela individualização em função do outro, constituir uma identidade tendo como base a condição de pertencimento é mais um teatro irônico de nosso tempo.

Não se deve conceber a desumanização como um estado definitivo da condição humana, mas como um processo. Entendendo-a como um processo, também devemos compreendê-la, a propósito, como um discurso, uma forma de categorizar as oscilações nas relações humanas. Foi devido a Michel de Foucault que conseguimos entender que o poder é plural, e não singular ou uno como bem queriam as classes burguesas. Dessa maneira, Barthes (1977) pontua que “[...] o poder é, simetricamente, perpétuo no tempo histórico: expulso, extenuado aqui, ele reaparece ali; nunca perece; [...]" (BARTHES, 1977, p. 6). Versada como um discurso, a própria ideia de desumanização empreendida neste trabalho implica a sua classificação; e toda “[...] classificação é opressiva [...]” (BARTHES, 1977, p. 6).

Veremos onde é mais apropriado o aprofundamento destas questões de identidade e desumanização, que o poder fragmentado, a cultura, o sistema capitalista e demais fatores de ordem social, promoveram diversas anomalias sociais que estão enfaticamente deslocando o sujeito para o nível obtuso (confuso) de si e, a partir disso, defrontamo-nos com uma questão já percepcionada por Étienne de La Boétie, em O Discurso Sobre a Servidão Voluntária, a saber, a figura do sujeito oprimido coercitivamente pelo outro é substituída pela opressão voluntária, pelo amor ao sofrimento; de ser escravizado. Esta questão pode se apresentar como uma problemática simples, contudo, como veremos, tratar-se-á não de um mero fenômeno, mas de uma anomalia intrigante e que merece especial atenção no decurso de nossa empreitada.

enquanto condição de existir-para” (BAUMAN, 2007, p. 13, Grifo do Autor). Difundido no pré-modernismo, a premissa era corrobora por princípios de ordem religiosa que atenuavam a responsabilidade moral pelo outro, em face disso, Bauman (2007) acrescenta: “Apropria essência das soluções religiosas da ambivalência consiste, por assim dizer, numa operação retrospectiva, que fornece meios destinados a contrabalançar o peso de uma escolha infeliz" (BAUMAN, 2007, p. 15, Grifo do Autor). 
No que concerne à temática "alienação", observamos, em nosso trabalho, que Franz Kafka, em A Metamorfose, conto publicado originalmente em 1916 em edição alemã, inicia do seguinte modo: "Certa manhã, ao despertar de um sonho inquietante, Gregor Samsa descobriu-se em sua cama transformado num insuportável inseto" (KAFKA, 2009, p. 29). É imperativo que justifiquemos a nossa escolha. O conto problematiza, como dissemos, questões referentes à alienação, mas não apenas isso; põe em evidência, certamente, e, precisamente, a ruptura do liame na forma como o sujeito se encontra e o modo como este sujeito é percebido pela sociedade.

No caso do protagonista da história, Gregor Samsa, mesmo na condição de inseto, não sendo mera representação pela ênfase que se constitui em torno do personagem, as pessoas que fazem parte de sua vida - amigos e familiares - não o enxergam mais como indivíduo humano, mas como alguém que não deveria largar o automatismo rotineiro do trabalho. O normal para os pais do protagonista era o paradigma de um individuo ligado, centrado no trabalho e na subserviência ao patrão.

A ruptura se dá quando Gregor se torna inseto, anomalia que já era naturalizada na concepção do conto e que, em justa medida, contrapõe-se ao paradigma do homem organizado, fiel ao trabalho e à família. A desumanização, em fase de metástase avançada como num câncer, tornou-se inerente ao indivíduo pós-moderno, algo natural e sem problematização.

A Metamorfose kafkiana é um procedimento transformativo que envolve, de modo complexo, a construção de uma consciência individual sobre as múltiplas relações que inserem o valor do sujeito para o mundo de que ele faz parte. $\mathrm{O}$ enredo problematiza as transformações que o capitalismo produziu, deliberadamente, na estrutura familiar e nos modos como a vida rotineira do trabalho se sobrepõe à própria condição do sujeito. Gregor é um personagem caracterizado pela assiduidade no trabalho, pontualidade, boa obediência ao patrão. Porém, quando Gregor se torna um inseto e começa a faltar ao trabalho com recorrência, entra em ação a participação da família que, mesmo o enxergando como um inseto ( a barata), defende que o filho deve continuar trabalhando e obedecendo ao patrão.

\section{Modernidade e pós-modernidade: o possível nascimento da desumanização na literatura}

Como ponto de partida, problematizamos a acepção que Kafka atribuiu ao termo "Metamorfose" ou transformação. Em virtude disso, a que tipo de transformação Kafka 
(2009) estava se referindo em sua obra? Numa escala generalizada, o escritor tentou reproduzir, através do personagem Gregor Samsa, que as transformações sociais promovidas pelas revoluções industriais, sobretudo pelo capitalismo ocidental, afetaram o homem não apenas no aspecto tecnológico aprimorado pelas grandes indústrias, mas também como essas transformações em nível global produziram uma consciência que tinha como objetivo a normatividade da alienação sem o significado de negatividade. No fragmento, “o rapaz não tem mais nada na cabeça a não ser a loja", notamos o primeiro aspecto que diz respeito à docilização de Gregor, por sua mãe e seu pai, em conversa com o gerente, veja: Eu até fico irritada, porque ele nunca sai à noite; agora mesmo, ele esteve oito dias seguidos na cidade, mas ficou em casa todas as noites" (KAFKA, 2009, p. 38-39, grifo nosso).

Note-se, neste segundo fragmento, a presença da representação do gerente, que vai visitar Gregor a fim de saber de por que o empregado não estava indo ao trabalho: "Gregor, agora falava o pai, do cômodo à esquerda, 'o senhor gerente veio até aqui e quer saber por que você não partiu com o primeiro trem'” (KAFKA, 2009, p. 38). Nas duas citações, é possível deduzir que a sobreposição do trabalho se constituía como evento mais importante do que o bem-estar de Gregor, à medida que este foi representado como um trabalhador assíduo, pontual e recatado, em suma, um trabalhador passivo e acrítico.

Portanto, na relação patrão-empregado, por exemplo, está presente a relação de subserviência do empregado ao patrão. Em outras palavras, engendra-se o princípio de inferioridade em relação ao outro. Subtrair o outro em função de uma posição social é, também, uma forma descortinada de poder. Deste modo, como entende Barthes (1977), isso constitui o discurso de poder, visto que "[...] todo discurso engendra o erro e, por conseguinte, a culpabilidade naquele que o recebe" (BARTHES, 1977, p. 6). Observando isso na ótica de Schopenhauer (2001), percebemos que o filósofo inicia a sua obra com o seguinte aforismo: “[...] o mundo é a minha representação" (SCHOPENHAUER, 2001, p. 9), assim, readaptando isso, dizemos no pretérito imperfeito, e, portanto, entendemos que o mundo era a minha representação.

Após a transição da modernidade para a pós-modernidade, o liame que fixava o sujeito ao mundo e ao outro dissolveu-se. Novos paradigmas sofreram mutação e, em face disso, Bauman (2007) estabeleceu a dicotomia paradigmática entre os valores da modernidade e da pós-modernidade, pontuando que, “[...] se o problema da identidade moderna era o de construir uma identidade, mantendo-a sólida e estável, o problema da identidade pós-moderna é em primeiro lugar o de como evitar a fixação e manter as opções em aberto" (BAUMAN, 
2007, p. 88). Essa mutação de valores implica inferir que passamos a adotar, como valores morais e éticos, a desvalorização desses próprios valores, em razão de um padrão de vida fundamentado na incerteza sobre as coisas ${ }^{6}$.

O paradoxo, por si só, é confuso (obtuso), mas coerente para esse entendimento. Entretanto, esse fator anômalo não fora percebido apenas desembocando na pós-modernidade, pois, observando o que descreve Étienne de La Boétie, humanista e filósofo francês, contemporâneo de Michel de Montaigne, em O Discurso Sobre a Servidão Voluntária, percebemos que:

Digno de espanto, se bem que vulgaríssimo, e tão doloroso quanto impressionante, é ver milhões de homens a servir, miseravelmente curvados ao peso do jugo, esmagados não por uma força muito grande, mas aparentemente dominados e encantados apenas pelo nome de um só homem cujo poder não deveria assustá-los, visto que é um só, e cujas qualidades não deveriam prezar porque os trata desumana e cruelmente (BOÉTIE, 2006, p. 7, grifo nosso).

Alinhado a esse filamento, compreendemos que Boétie já notara um fenômeno importantíssimo de sua época, a servidão voluntária e a multiplicidade do poder ${ }^{7}$. O que levou as sociedades humanas a se encantarem por sua própria dominação, no tocante ao outro? É “doloroso quanto impressionante”, diz Boétie (2006, p. 7), ao descrever o absurdo à que se chegou a condição humana. A título de contextualização, o mesmo fenômeno, com roupagem diferente, repete-se mais de 600 anos depois de Boétie, na modernidade tardia. Em consonância com o paradoxo proposto nesta pesquisa, o sujeito do século XXI é o sujeito que ama o erro, idolatra-o, venera-o; que é agente majoritário das concupiscências e infâmias.

As novas gerações são corporificadas espiritualmente e geneticamente, para defenderem - não o extermínio desses novos paradigmas - mas a sua permanência. É nisso que consiste a nova identidade novecentista, um processo confuso e não centralizado. Kafka (2009), em A Metamorfose, nos trás alguns questionamentos acerca de nossa própria

\footnotetext{
${ }^{6}$ Se na sociedade tradicional dos séculos XVIII e XIX, por exemplo, era proibido as mulheres fazerem sexo abertamente com vários homens, em finais do século XX para o século XXI, isso já é natural, permitido.

${ }^{7}$ No entendimento de Roland Barthes e José Luiz Fiorin, Michel de Foucault foi quem nos iluminou acerca da multiplicidade do poder, isto é, que ele não é uno. Não obstante, depreende-se que talvez Foucault não tenha sido o primeiro a notar esse caráter fragmentado poder, pois, como vimos Étienne de La Boétie criticava a subserviência a um só homem, dando margem para que captássemos o implícito: o poder também emanava do povo, se estes, naturalmente, largassem a servidão voluntária e se unissem contra a tirania.
} 
constituição, a saber: qual a condição para nos conscientizarmos de nossa própria alienação?; Em que circunstância nós abandonamos a nossa unidade, a nossa consciência em função da "mecanificação" das correntes transformações sociais?

Ao propormos responder a essas questões, optamos por analisar o Conto na perspectiva do discurso e, quanto ao autor, analisaremos como sujeito e não como escritor. O discurso é proferido através de uma língua e toda língua (escrita ou falada) está carregada de significados. Portanto, como defende Martelotta:

Os linguistas funcionais defendem a ideia de que a estrutura da língua reflete, de algum modo, a estrutura da experiência. Como a linguagem é uma faculdade humana, a suposição geral é a de que a estrutura linguística revela o funcionamento da mente, bem como as propriedades da conceptualização humana do mundo (MARTELOTTA, 2012, p. 167, grifo nosso) ${ }^{8}$.

Pelo fragmento, podemos inferir, provisoriamente, que a língua é depositária das experiências de um sujeito e, a partir da conservação dessas experiências vivenciadas pelo indivíduo, este se utiliza destas para conceitualizar o mundo em sua volta. Deste modo, como comenta Fiorin (2009, p. 150), “a língua não é uma nomenclatura, que se opõe à uma realidade pré-categorizada, ela é que classifica a realidade”. A partir desse ponto de vista, podemos presumir que a alienação, em linhas gerais, não é uma ideia "coisificada" que faz parte do cotidiano de uma dada comunidade, mas é, sobremaneira, a representação da força histórica, econômica, política e cultural que engoliu vorazmente os séculos anteriores e está engolindo o nosso atual século. Assim, somente com a Globalização, como sublinha Hall (2006) e Bauman (2007), é que estamos vivenciando brutais alterações nas estruturas sociais que implicam não apenas incidências na atividade material da sociedade (exterior), mas também na interioridade do indivíduo, isto é, nas mutações ocorridas na esfera psicológica, as quais confluem com mutações na vida material.

Nesse sentido, Zygmunt Bauman, em A Vida Fragmentada, deduz que conforme os sujeitos se individualizam, mais se torna constante o enlevo pela dissolução de si e, em justa medida, a barbárie vai se modelando numa sociedade estratificada e ratificada pela incerteza. Sobre isso, Boétie (2006) descreve, precipuamente, o fator anômalo de o (s) sujeito (s), por sua própria conta, sujeitarem-se à barbárie, apontando para questionamentos que indagam a respeito de:

\footnotetext{
${ }^{8}$ Excerto extraído do livro Manual de Linguística organizado por Mário Eduardo Martelotta. O excerto em questão é de autoria de Angélica Furtado da Cunha.
} 
Que nome se deve dar a esta desgraça? Que vício, que triste vício é este: um número infinito de pessoas não a obedecer, mas a servir, não governadas mas tiranizadas, sem bens, sem pais, sem vida a que possam chamar sua? Suportar a pilhagem, as luxúrias, as crueldades, não de um exército, não de uma horda de bárbaros, contra os quais dariam o sangue e a vida, mas de um só? [...] (BOÉTIE, 2006, p. 8, grifo nosso).

Na luz do entendimento dessa citação, podemos presumir que o poder é múltiplo, que ele está presente em todos os lugares e pormenores da atividade humana, e querer fazer o bem é uma forma de poder; de igual modo, querer fazer o mal também é uma forma de poder. Antes de Foucault, acreditava-se piamente que o poder fosse uno, que ele pertencesse apenas aos grandes reis ou personagens da história ocidental, como Alexandre o Grande ou aos Faraós do Egito. No entanto, muitos eventos ocorreram do século XIX em diante, a saber, a fragmentação da identidade, as concepções de poder e sua dimensão política e, não menos importante, a ratificação de uma sociedade estratificada, reificada e apresentada nos moldes do superior e do inferior - A Deusa Globalização.

Ao observar esse ponto de vista, pela ótica de Barthes, previu-se que:

Adivinhamos então que o poder está presente nos mais finos mecanismos do intercâmbio social: não somente no Estado, nas classes, nos grupos, mas ainda nas modas, nas opiniões correntes, nos espetáculos, nos jogos, nos esportes, nas informações, nas relações familiares e privadas, [...] (BARTHES, 1977, p. 6).

Desse modo, se, portanto, o poder não constitui apenas a esfera do Estado, logo se deduz, a partir do que Barthes (1977) afirma, que ele é onipresente, onisciente, que perpassa os séculos e que está em todas as camadas sociais. No fio desse raciocínio, inferimos que a desumanização pode ser pensada como uma das manifestações do poder que está presente no mundo inteiro e que, por sua natureza, está tiranizando as pessoas, como enfatiza Boétie (2006). Na verdade, no ponto de vista da nossa pesquisa, entende-se que a tirania está presente em todas as pessoas, não apenas nos políticos, latifundiários, empresários etc., mas também em todos nós.

À medida que nos tornamos tiranos e, por conseguinte, individualistas em níveis extremos, essas relações que antes poderiam se enquadrar à constituição conceptual de nossa subjetividade, agora se tornam práxis, ganhando relevo em si mesmo, ao passo que essa anomalia se alimenta de si própria, engendrando o conformismo e a sua posterior naturalização. Em relação a isso, Gregor Samsa, protagonista do conto kafkiano, torna-se o catalisador de todo esse processo alienante; alguém que já não entende a sua própria condição 
humana e, por isso mesmo, adere ao estado desumanizador numa sociedade já engolida pelo implacável advento da modernidade.

\section{Entre as mutações e obscuridades na literatura pós-moderna: o discurso da decadência humana}

O que representa o movimento ocorrido no século XIX, de cuja nomenclatura Realismo? Sumariamente, o realismo fora um movimento em contraposição aos valores defendidos pelo romantismo, movimento que surgiu nas últimas décadas do século XVIII e que se desenvolveu plenamente no século XIX. O realismo surge na Europa, especificamente na França e depois se expande para Portugal e demais países ocidentais. Alguns dos princípios que compuseram a estrutura desse movimento baseavam-se no objetivismo, no cientificismo e na ponderabilidade das emoções e/ou sentimentalismo.

Na França do século XIX, alguns autores foram percussores do movimento, a saber, Gustave Flaubert, autor de Madame Bovary, Emile Zola, autor de Germinal e, não menos importante, Charles Baudelaire, autor de As Flores do Mal (1857). Em Portugal, os principais nomes do Realismo são Eça de Queiroz e Antero de Quental. Este último publicara uma obra poética - Primaveras Românticas (1872). De Eça de Queiroz, tem-se o clássico O Crime do Padre Amaro (1875). No Brasil, o realismo foi inaugurado em (1881) por Machado de Assis, com a obra Memórias Póstumas de Brás Cubas. Também podemos citar Lima Barreto, com uma de suas obras intitulada Clara dos Anjos (1948), e outro autor da cidade de Sapé - PB, também do século XIX - Augusto dos Anjos, com o livro Eu (1912).

No âmbito desse movimento filosófico-literário, o protótipo do homem em interface com a modernidade e a pós-modernidade, foram anunciados os efeitos nocivos do capitalismo na fragmentação da personalidade do homem, que agora poderia ser inserido em um contexto maior, pluralizando-o, irrompendo com concepções homogêneas que objetificavam o sujeito como impassível de constituir-se como múltiplo, em termos culturais. Algumas produções literárias, do século XIX em diante, são inventários de experiências reclusas da vida privada dos indivíduos, que, ao abandonar o subjetivismo romântico, passam da homogeneização de si para a sua pluralização ofertada pela modernidade; desde então, a modernidade vem questionando os sujeitos a respeito de quem os são.

Machado de Assis, no conto A Cartomante (1884), expõe o pior do ser humano, a decadência das crenças, a traição e, como resultado, a ratificação do ódio impressa na morte de Camilo por seu melhor amigo, Vilela. Lima Barreto, em Clara dos Anjos (1948), exibe o 
panorama do preconceito, do racismo, da miséria, características nítidas na protagonista Clara, uma jovem mulher bonita, mulata e enganada por um moço burguês e galanteador, que a desonra e depois foge.

Nesse romance, vê-se a representação de uma sociedade tradicional, onde era dever da mulher ficar em casa e se centrar nos afazeres. O prenúncio da desumanização nas produções literárias reflete, substancialmente, a preocupação de alguns escritores e pensadores, no que toca às relações sociais. Deste modo, argumenta Hall (2006 apud MARX \& ENGELS, 1973, p. 14) que a modernidade:

[...] é o permanente revolucionar da produção, o abalar ininterrupto de todas as condições sociais, a incerteza e o movimento eternos [...] Todas as relações fixas e congeladas, com seu cortejo de vetustas representações e concepções, são dissolvidas, todas as relações recém-formadas envelhecem antes de poderem ossificar-se. Tudo que é sólido se desmancha no ar [...].

Do ponto de vista da citação, cabe presumir que é intrigante pensar na condição da desumanização, pois atenta para o fato de que a humanidade está corporificando práticas que outrora eram tidas como fabulares e subjetivas. A literatura, após o realismo e, consequentemente, com a pós-modernidade, está saindo do mundo ideal e se projetando no mundo real. A Divina Comédia: o Inferno (1320), do escritor italiano Dante Alighieri, lá no século XIII, exibe, em nível erudito, a inerência do homem ao erro, tal como a sua deficiência em superar seus próprios pecados.

Como consequência das transgressões em vida, o homem enfrentara os piores castigos que se poderiam imaginar. No liame dessa narrativa, pode-se inferir, precisamente, que a ornada criação dos demônios por Dante possa, sem perjúrio, ser alinhada à natureza do homem pós-moderno. O ostracismo do sujeito moderno em busca de uma unidade consigo e com o mundo coloca-o contíguo aos aspectos de um demônio tal como delineado por Dante.

Essas novas objeções acerca da supressão do indivíduo como humano e a sua mutação passando a praticar a incerteza é um fenômeno observado, nas artes e na estética do século XIX, por Gasset (2001), quando ele escreve que, “[...] longe de o pintor ir mais ou menos entorpecidamente à realidade, vê-se que ele foi contra ela". Propôs-se decididamente a deformá-la, romper seu aspecto humano, desumanizá-la" (GASSET, 2001, p. 41). Em sua obra, A Desumanização da Arte, o autor levanta uma discussão acerca do distanciamento que se entrepõe nas expressões artísticas com a realidade, isto é, a crítica é que as novas artes estão produzindo suas criações baseadas em elementos que não fazem parte da realidade, impossibilitando, por sua vez, a depreensão de seus significados. 
À medida que o sujeito se utiliza de recursos artísticos, sem levar em contrapartida o objeto para quem se destina a sua produção (o ser humano), o artista, segundo Gasset (2001), está praticando a desumanização, ou seja, instaurando o distanciamento entre a realidade em que vivemos, com a realidade obscurecida e sem sentido nas produções artísticas. Desta maneira, "[...] a arte de que falamos não é só inumana por não conter coisas humanas, senão que consiste ativamente nessa operação de desumanizar” (GASSET, 2001, p. 42).

Com efeito, o discurso da decadência humana no âmbito das produções literárias na pós-modernidade não se trata de um fenômeno a priori, mas de um câncer que, desde Étienne de La Boétie, vem crescendo e aprimorando-se. E o discurso tem por veículo a língua, que, excepcionalmente, no plano da linguagem literária, enquadra-se precisamente na definição de Barthes (1977), uma vez que "a língua, como desempenho de toda linguagem, não é nem reacionária, nem progressista; ela é simplesmente: fascista; pois o fascismo não é impedir de dizer, é obrigar a dizer" (BARTHES, 1977, p. 07).

A língua é uma forma de categorizar o mundo, como afirma Fiorin (2009), e se, portanto, ela categoriza, logo depreendemos que antes de a desumanização vir a ser uma prática concreta, ela fora construída com base num discurso que prioriza a radical separação do sujeito da realidade. E se inibir o sujeito da realidade enquadra-se numa prática de desumanização, logo Saussure - linguista suíço do século XX - pode ser considerado um precursor da desumanização no âmbito da linguagem, quando, por conseguinte o que:

[...] faz na sua teoria do signo é separar radicalmente a linguagem da realidade. Com isso, o que ele propõe é que a ordem do mundo é diferente da ordem da língua, pois esta não é um reflexo da realidade, mas uma criação do homem. Portanto, é radicalmente histórica (FIORIN, 2014, p. 57).

A linha que separa a linguagem e a realidade é tênue e um tanto perigosa para pô-la numa redoma conceptual. Perigosa, porque a língua, inerente à espécie humana, não é um mecanismo estagnado, imóvel, mas está em constante movimento, em transformação. Forma e expressão concorrem para novas operações de classificar essas estruturas maleáveis. Nessa linha de raciocínio, não se deve compreender a realidade separando-a da língua, ao contrário, deve-se adotar como contrapartida a sua interação.

\section{Considerações finais}

Como quociente desta pesquisa, aferiu-se que o escritor alemão Kafka, através da construção do personagem Gregor Samsa, problematizou a construção da consciência a partir 
do processo capitalista que afetava não apenas aqueles que trabalhavam, mas também a estrutura de organização familiar, uma vez que "Ele só toma consciência de sua alienação ao ser alienado de sua forma humana"” (KAFKA, 2009, p. 21).

A alienação de que trata Celso Donizete Cruz, vai se caracterizando como um processo que se naturaliza, uma vez que a própria família de Gregor aceita como normalidade o fato de o seu filho ter se tornado uma barata à medida que ele ia se entregando à força explosiva do capitalismo.

A desumanização, em linhas gerais, não é um fenômeno abstrato e, a priori, no contexto da produção literária objetificada nesta pesquisa, ela é, por conseguinte, uma práxis social e coletiva. E antes que qualquer prática concreta venha a se materializar, ela é, sobretudo, um discurso, e, todo discurso, por sua natureza, utiliza-se da linguagem como seu canal de expressão fundamental.

No liame dessa discussão, inferimos que a desumanização teve como sua mais notável manifestação o Realismo ocorrido na França do século XIX. Contudo, os alicerces desse discurso começaram a se formar, como vimos, desde Étienne de La Boétie, século XVI, em sua obra $O$ Discurso Sobre a Servidão Voluntária. Exibimos, a rigor, a intrínseca relação entre a língua, o discurso, o poder e as complexas operações que se desenvolveram por via da alteridade na pós-modernidade. Trabalhamos, com afinco, no protótipo da representação e da identidade do novo sujeito, após as diversas transformações sociais que se deram desde a transição do feudalismo até o capitalismo, no fim da Idade Média.

Stuart Hall (1932-2014) e Zygmunt Bauman (1925-2017) revelam o caráter descentralizado do novo homem, um sujeito que abdicou de sua unidade para aderir às múltiplas identidades e, por consequência, à conservação da incerteza. Hall (2006) argumenta que no fim do século XX algumas coisas ocorreram às sociedades humanas, decorrentes de todo o processo capitalista moderno, e esses processos estão fragmentando o sujeito, fazendoo se afogar num oceano de múltiplas personalidades.

\section{Referências}

\footnotetext{
${ }^{9}$ Interpretação de Celso Donizete Cruz, professor na área de Letras pela USP (Universidade de São Paulo) e que foi responsável por escrever a introdução do livro Metamorfose pela editora Hedra.
} 
BARTHES, Roland. Aula. 14a . Ed. São Paulo: Cultrix, 1977.

BAUMAN, Zygmunt. A Vida Fragmentada: ensaios sobre a moral pós-moderna. Lisboa: Relógio D’Água Editores, 2007.

BAUMAN, Zygmunt. Identidade: entrevista a Benedetto Vecchi. Rio de Janeiro: Zahar, 2005.

BOÉTIE, Étienne de La. Discurso Sobre a Servidão Voluntária. [S.1.: s.n.], 2006.

CANDIDO, Antonio. Vários Escritos. 5ª Ed. Rio de Janeiro: Ouro Sobre Azul, 2011.

ELIADE, Mircea. O Sagrado e o Profano. São Paulo: Martins Fontes, 1992.

FIORIN, José Luiz. Língua e História em Saussure. Rio de Janeiro: Matraga, 2014.

FIORIN, José L. Língua, Discurso e Política. Rio de Janeiro: Alea, 2009.

GASSET, José Ortega y. A Desumanização da Arte. São Paulo: Cortez, 2001.

HALL, Stuart. A Identidade Cultural na Pós-modernidade. $11^{\mathrm{a}}$. Ed. Rio de Janeiro: DP\&A, 2006.

KAFKA, Franz. A Metamorfose. São Paulo: Hedra, 2009.

MARTELOTTA, Mário Eduardo et al. Manual de Linguística. São Paulo: Contexto, 2012.

NIETZSCHE, Friedrich. Assim Falou Zaratustra. São Paulo: Companhia das Letras, 2011.

SCHOPENHAUER, Arthur. O Mundo como vontade e representação. Rio de Janeiro:

Contraponto, 2001. 